\title{
Student Literacy Trough Balinese Temple Brochures
}

\author{
Gusti Ayu Putu Diah Permata Sari AR ${ }^{1}$, I Putu Yoga Purandina ${ }^{2}$, Made Novita Dwi Lestari ${ }^{3}$ \\ Communication Science, STAH Negeri Mpu Kuturan Singaraja ${ }^{1}$, Early Childhood Teacher \\ Education, STAH Negeri Mpu Kuturan Singaraja ${ }^{2}$, Hindu Cultural Tourism, STAH Negeri Mpu Kuturan \\ Singaraja ${ }^{3}$ \\ \{diahpermatasari.ar@gmail.com\}
}

\begin{abstract}
Literacy is one of the essential factors that support students 'success in everyday life. Through brochures, the students could create meaningful activities during literacy sessions. This study aims at describing student literacy through Balinese temple brochures. The research was design using a qualitative approach. The subject of study were students in the third semester of Penerangan Agama Hindu study program, STAHN Mpu Kuturan Singaraja. The data were collected through observation, questionnaire, and interview. The result of the study showed that brochures were helpful to increase student's English skills. As well as the students would be able to enrich English vocabulary which is useful for their comprehension. The students also more realized that English can be beneficial for their future careers.
\end{abstract}

Keywords: Literacy; Balinese Temple Brochures; English Skills

\section{Introduction}

In simple terms, literacy is the ability to read and write. The ability possessed by a person in processing and understanding information through reading and writing activities [1]-[3]. Although recently the notion of literacy began to develop. There are media literacy, economic literacy, health literacy, digital literacy, etc. But the main thing in literacy is actually reading and writing [4], [5]. This ability must be mastered by each individual as a soft skill that will later help the individual to be able to adapt and carry out self-development in his environment.

Furthermore, literacy is a means of recognizing, understanding, and applying knowledge [6], [7]. Without this ability, of course, you will not be able to absorb or process information intelligently, effectively, and wisely. Ability to access, understand, and use information intelligently through various activities, including reading, viewing, listening, writing, and speaking. Then literacy is also the ability to read, write, view, and design things, accompanied by the ability to think critically which causes a person to communicate effectively and efficiently so that it is beneficial for himself and others [8], [9]. So that it can be said that literacy is the ability to speak in communicating with the environment.

This literacy ability cannot be separated from the language ability itself. To strengthen literacy, language skills must also be strengthened [10], [11]. So that language is the key to the success of a person's literacy skills. This language ability should always be honed. In this era of society 5.0, it is not enough for every individual to only master one language but must be able to master international languages such as English. English is an international language that is used in communication throughout the world [12]. In this digital era, information that is accessed and processed is various information from all over the world, most of which use 
English as an introduction. Likewise, in communication. Today communication can be done remotely using various communication applications and social media.

Thus, literacy concerning English must be nurtured from an early age. English literacy as the ability to read and write in English and also using appropriate expressions in English, especially in written form [13]. This can be done in an integrated manner through learning English by utilizing interesting learning media and can improve one's literacy skills [14], [15]. So that the expected results can increase in tandem. English proficiency increases, as well as literacy skills in English also increases. These two things are very closely related. It cannot only improve English language skills, without the process of accessing and processing information effectively, efficiently, intelligently, and wisely. Likewise, communicating globally by using English wisely.

As was done in learning English in the English Application course at the Penerangan Agama Hindu Study Program, the Dharma Duta Department, STAHN MPU Kuturan Singaraja was introduced to learning media in the form of English brochures in the English Language Application lecture. The brochure used here is a brochure about the information on various temples in Bali. The brochure contains detailed information about the history, philosophy, and description of the location and form of the temple in English. By using this brochure, learning activities in lectures are designed by using the information in the brochure to practice the four skills in English. These four skills are reading, listening, writing, and speaking. In addition, they can understand information, and exchange information wisely.

Brochures are information media that have the function of disseminating information or promotions related to something, both regarding the information on a place, object, or product, as well as activities, public services [16], [17]. The brochure is printed on two sides, folded in a certain pattern so that it can be seen from various sides for more efficiency. Brochures are used to make information easier to understand in a short time. Brochures are designed as attractive and simple as possible so that people will be interested in reading and understanding the information you want to explain or disseminate [18], [19]. Brochures are general which are intended for everyone so that the language used is common and easy to understand. Arranged systematically to make information easy to understand chronologically.

Having a language that is easy to understand and systematically arranged, makes brochures suitable as a learning medium. In addition, the brochure also has an attractive and simple design, so that students can be enthusiastic about learning English [20], [21]. Good learning media are media that are following the learning objectives themselves, the characteristics of the media are following learning activities, being able to support learning content, easy to obtain, easy access, does not take a long time to use, media compatibility with the way students think, following the situation and environmental conditions, according to the ability of the teacher or lecturer, and effective in supporting lectures in terms of time, place, etc.

In ELT the media has a very vital role to develop four English skills, reading, listening, writing, and speaking. These four skills are developed through various learning activities that can train and improve students' ability to speak English [22], [23]. Learning media and learning activities must be related and have goals according to the expected indicators [24]. Furthermore, learning media is a tool, material, or condition that is used to support the learning process, as an intermediary for communication, as a form of system concept, and learning concept [25]. So that the brochure is fulfilled as a learning medium. Even brochures are real objects that are used as learning media. Has a high authenticity value that can later be used by students in the real world.

In a study conducted by Sari and Syafei in 2013 that tourism brochures can improve the English skills of vocational school students. In addition, students can find out new information 
and make students more active and creative in learning activities [26]. Research conducted by Sukaton in 2013 as well as by Kurniawan and Rosa, researched the use of brochures for junior high school students to improve students' speaking skills. Students become aware of their ideas in speaking using brochures [27]. Research In 2021 by Joraboyev from Russia explained that brochures are authentic media that can motivate students and make students more comfortable. They can learn through their environment, utilizing objects or media that exist directly from the environment, making them easier to understand and more comfortable [28]. Likewise, the research conducted by Damanhouri in 2021 with scaffolding learning, one of which was using brochure media. Students show a positive attitude and good motivation in learning [29].

Seeing from various previous studies in the use of brochure media in ELT shows a positive impact in supporting the learning process and improving students' English skills. Both the four skills such as reading, listening, writing, speaking, and can increase students' motivation, good behavior, comfort, and confidence. Taking this into account, the researcher wants to conduct further investigations into the use of brochures, in this case, the Balinese Temple Brosure used in the ELT class for the English Language Applications Course, Information Study Program, Department of Dharma Duta, STAHN Mpu Kuturan Singaraja. Can using this brochure improve their English skills and mastery of English vocabulary for their future career development?

\section{Research Methods}

This research was categorized as descriptive qualitative research which the data was gathered through observation, questionnaire, and interview. The observations were conducted during four meetings. Observation is defined as a basic method for obtaining data in qualitative research and the purpose is to understand complex interactions in a natural setting [30]. In this case, the researcher collected the data about student literacy through Balinese temple brochures during the third semester of Penerangan Agama Hindu Study Program, STAH Negeri Mpu Kuturan Singaraja. The researcher observed how the students used the Balinese temple brochures as media during literacy sessions. Thus, the result of observation would be able to support the data in this research.

In addition, the researcher conducted the interview session. Interview was done to get a deeper understanding of the phenomenon which couldn't be gained through observation alone. The researcher used a structured interview which is getting certain information from the subject. In this case, the interview session was done to know the students' responses after literacy sessions. The researcher chooses two students as representatives to answer some questions during the interview session. And the last, the questionnaire was given to all students of the third semester at Penerangan Agama Hindu Study Program, STAHN Mpu Kuturan Singaraja. The questionnaire items are displayed in the google form. 8 students in the class participated in filling the questionnaire. Besides, the students were instructed to give marks which are shown in the google form questionnaire. Each answer had to be assessed using the formula shown below:

$$
\text { Percentage: } \frac{\text { Total score }}{\text { Total of students }} X 100 \%
$$

The result of the questionnaire was used to collect the data more accurately. As well as, in analysing the data, the researcher used an interactive data analysis model which was developed by Miles and Huberman. There are four steps in this model namely data collection, data reduction, data display, and drawing conclusion and verification [31]. Besides, the researcher relied on triangulation to enhance the validity and reliability of the data. Triangulation is defined 
as the use of two or more methods of data collection in the study of some aspect of human behaviour [32][33]. Thus, the results of the data were measured correctly and avoid some errors during this study.

\section{Results and Discussion}

According to the result of the observation, it could be found that literacy through the Balinese Temple Brochures helped the student easier in learning English. In this case, the researcher noticed that the students started the activity with analysed and read the Balinese Temple Brochure delivered by the lecturer. After that, the lecturer attracted the students by asking some questions related to brochures. In this activity, the student tried to answer the questions by using the English language. Even though they had limited vocabulary, the lecturer will have helped them to give additional information. Thus, the students had learned new vocabularies which suitable for the lesson.

In addition, the researcher found that the students also developed their English skills by creating Balinese Temple Brochure in English. They started to choose the Balinese Temple which they wanted to describe in the brochure. Then, the students designed the brochure by using a photo-editing application. The students looked more enthusiastic during this activity. They could work individually or even with their classmates. As well as they also applied new vocabulary in writing their brochure. Sometimes, the lecturer will be checked the student project and gave some suggestions during literacy sessions [34].

This statement is also supported by the result of the questionnaire. In this case, the researcher asked the students to fill the questionnaire in the google form. There were ten questions displayed in the questionnaire. Those questions items include (1) The students can recognize English vocabulary through the brochure, (2) The students can understand the content in the English brochure, (3) The students can pronounce the words and sentences in brochure, (4) The students can find the accurate information through English brochure,(5) The students can find the meaning of each word and sentence in Bahasa, (6) The students can write and design English brochure, (7) The students can convey the content of brochure in English, (8) The students have the motivation to learn English language through the brochure, (9) The students can improve their English vocabulary through brochure, (10) Literacy through English brochure will use for the future carrier.

In addition, the instructions and question items were also added in Bahasa. As well as there were five scales showed in the questioner. Those scales included strongly disagree (1), disagree (2), neutral (3), agree (4), and strongly agree (5). The students were expected to be able to answer the question items naturally. The result of the questionnaire is shown below:

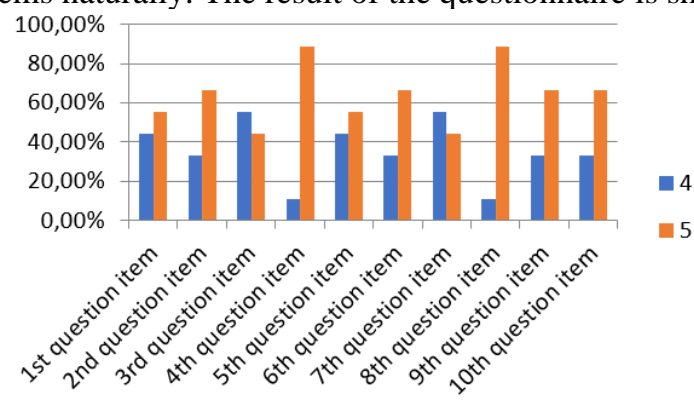

Fig 1. The result of the student questioner 
The result of questioner showed that most of the students were ticked point 4 (agree) or even point 5 (strongly agree) on questionnaire items. It was assumed that the Balinese temple brochure could give a positive impact on students during literacy sessions. The advantages of the brochure as media in teaching English such as students feel comfortable and enjoy studying, the brochure can help students to explore vocabulary to develop their English skills, the brochure can help the students to get new information and generate their ideas, and brochure is easy to apply, simple, and colourful [35].

All of those advantages were generated with the result of this study. In this case, the students could wider their vocabulary which is useful for students' language development. This is also connected with the result of the questionnaire showed $66.70 \%$ strongly agree and $33.30 \%$ agree that brochures could improve students' vocabulary. Vocabulary is one of the important aspects to support the students in mastering language skills. By mastering vocabulary, the students were expected to be able to minimize the problem in learning the language.

The students who had rich vocabulary tend to be easier in mastering essential English skills. In this study, the researcher observed the students were challenged to learn new vocabulary which useful for daily life. It was connected with the data which explained 55,6\% of students strongly agree and $44,40 \%$ of students agree that they were able to recognize their vocabulary through English brochure. When the students had many vocabularies, it would be easier in learning the language. Vocabulary is a core component of language proficiency and provides much of the basis for how well learners speak, listen, read, and write [36]. Some vocabularies items should be known by the student during learning the language. Those were nouns, pronouns, adjectives, verbs, adverbs, prepositions, determiner, and conjunction. In this case, the use of the Balinese Temple Brochure could be one alternative to enrich the student vocabulary. The students will know the specific vocabulary used in explaining the Balinese temple.

Moreover, the mother language had an important role in learning the target language. In the process of teaching the foreign language, the teacher's use of mother tongue can influence the learner's acquisition of the target language [37]. The use of mother tongue could help the students in understanding the new words and sentences which they did not know previously. In addition, mother tongue might be occasionally used, but teachers must keep in mind that exposure and practice is the main thing if they want to reach their teaching goals [37]. During the observation, the lecturer allowed students to find the meaning of each word and sentence in Bahasa. The students tried to find the meaning in a dictionary. As well as the students made small discussions with their friends to search the meaning. The lecturer directly asked the students to return to the target language when they already finished. So, the students could have a deep understanding of their language without forgetting their native language.

Besides, the data explained that $66,70 \%$ of students strongly agree and 33,30\% agree that students were able to understand the content in the English brochure. In this case, the lecturer showed the Balinese Temple Brochure which attracts the students' attention. The lecture used simple language which appropriates with students' prior knowledge. Good criteria of the brochure should be clear, attractive, brief, and a good brochure will grab the attention of the reader, provide needed information while inspiring the reader to take action [38]. The researcher found that students were interested in the content of the Balinese temple brochure which provided simple explanations and colourful pictures. Thus, the implementation of the Balinese Temple Brochure was suitable for the students themselves.

In addition, the students can find accurate information through English brochures. The result of the questionnaire found that $88.90 \%$ strongly agree and $11.10 \%$ agree there was accurate information in the English brochure. This was evidence by the result of the students' project during the literacy session. After the student read the example of the brochure, they 
designed the brochure individually. The students should describe the accurate information about the Balinese temple includes the brief history, the location, etc. As well, they can be given the picture to catch the reader's attention. The picture could help the students to imagine the real things of menus so they could understand about it although they had never eaten before [39]. In another word, through pictures, the students quickly to gain the content which displayed in the brochure.

The student activity in writing the content of Balinese Temple Brochures became the one of important components of the successful literacy session. This was because during this activity the students were expected to be able to apply the language aspects in the form of brochures. There were many aspects of language included grammar, spelling, idioms, vocabulary, and culture [38]. Sometimes, the several aspects could not be fulfilled by the students. That condition made them difficult to finish their writing. Therefore, the lecturer should find alternative media during writing activities such as writing the brochure. In the beginning, the researcher found that the student had lack ability in writing. In this case, the lecturer stimulated the students by introducing some interesting brochure and explained how to write the brochure in a good way.

In addition, the lecturer monitored the progress of students during the writing activity. Based on the interview, the student felt enjoyable in finishing their project. Their confidence also improved during this activity. They looked more active in developing their creativity. It was supported with the result of the questionnaire which showed $66.70 \%$ strongly agree and $33.30 \%$ agree that the students were able to write and design the Balinese Temple Brochure. All the students could submit the project based on the due time. Here the example of students works about Balinese Temple Brochure:

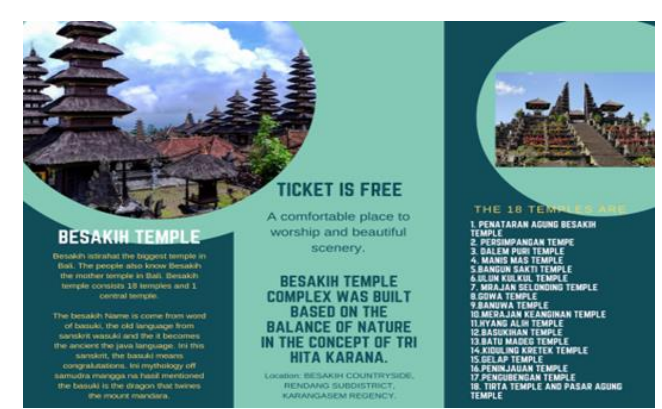

Fig 2. Besakih Temple Brochure

Furthermore, the finding of the research showed that brochures could improve students speaking ability. It was evidenced by the students' activity during the literacy session. The students should explain the content of their brochure by using the English language. Most of them were confident in sharing the information about their project. This was also connected with the percentage of the questionnaire where $44.40 \%$ strongly agree and $55.60 \%$ agree that the students were able to convey the brochure in English. This result was relevant to the nature of speaking where speaking is an action of conveying information or expressing one's thoughts and feelings in spoken language [39]. In practicing this speaking skill, the lecturer could give some corrections and suggestions about the students' performance.

In addition, pronunciation is one of the components of speaking ability. Based on the result of the questionnaire the students believed that they could pronounce the word and sentence in the brochure. It was evident by the result of the questionnaire showed the percentage was $44.60 \%$ strongly agree and $55.60 \%$ agree. In this case, the lecturer emphasizes pronunciation 
during the teaching and learning process. The aspects of speaking that should be learned are grammar, vocabulary, content, pronunciation, and fluency [40]. When the student was able to complete those aspects, they can be fluently in sharing their ideas and opinion during the communication. In this research, the researcher noticed the lecturer instructed the students to pronounce words and sentences in the brochure loudly. During this activity, the researcher found that some students did mispronounce in pronouncing new words and sentences in the brochure. They could not know how to pronounce it correctly. They only tried to find the meaning in Bahasa without regarding the pronunciation. In this case, the lecturer directly gave an example of how to spell those words and sentences with the correct pronunciation.

In another meeting, the researcher found that there was an improvement of students in pronouncing the word or sentence. This situation happened when the students explained their final project. The lecturer allowed the students for sharpening their speaking abilities. They could describe the content of the Balinese Temple Brochure clearly. Therefore, brochures became an important aspect to encourage students' motivation during the learning process. Based on the students' interviews, the students had high motivation to improve their English skills through the brochure. It was because literacy through brochures involved four essential English. This statement was supported with the result of the students' questionnaires which showed $88.90 \%$ of the student strongly agree that they could motivate to study English through brochures. Thus, it can be concluded that brochures could build up the spirit of students during English lessons.

Moreover, the researcher noticed that the literacy activity through brochures could give a beneficial effect on students. Generally, the students who graduate from Penerangan Agama Hindu study program would continue their carrier as Hindu preachers, employees in the Ministry of Religion, etc. Therefore, the literacy activity through Balinese Temple Brochures was appropriate with their major study. In addition, the result of the questionnaire was $66.70 \%$ strongly agree and $33.30 \%$ agree that literacy through brochures will be useful for their future carrier. The implementation of this media could realize the students with the importance of English in the job market. Through the brochure, the students acquire English vocabulary speaking skills that they require in their career purpose [41]. Thus, by mastering the English skill the students were expected to be able to raise better prospect carrier in the future.

\section{Conclusion}

Literacy is one of core component to be developed for students since early age. Especially for university students, literacy can be inserted during English lesson. Balinese Temple Brochures could delivery as learning media for university students. It was supported by there were some beneficial effects of using brochures in improving four essential English skills. As well as the students also felt enjoy and became active. They have opportunity to express their ideas and creativity through brochure.

In addition, the implementation of Balinese Temple Brochure would be to give more knowledge for students at Penerangan Agama Hindu study program. It was related with their major study which learn about philosophy of Hindus religion and how to transfer it through communication. Thus, this activity could help the students in getting their future carrier. The students could realize the important of English as language which provide positive impact in everyday life. 


\section{References}

[1] A. M. Shara, D. Andriani, A. W. Ningsih, and K. Shinoda, "Correlating Reading Literacy and Writing Literacy in Junior High School Pematangsiantar,” J. English Educ., vol. 5, no. 2, pp. 72-85, 2020, doi: $10.31327 /$ jee.v5i2.1249.

[2] S. Diana, S. Sianipar, and R. Harianja, "Literacy as an Effective Media for Distance Learning," vol. 2, no. 3, pp. 591-599, 2021.

[3] S. Nabhan, "Conceptions of Literacy in English Language Education Context," Proc. 2nd Annu. Conf. Soc. Sci. Humanit. (ANCOSH 2020), vol. 542, no. Ancosh 2020, pp. 203-206, 2021, doi: 10.2991/assehr.k.210413.047.

[4] G. Barton and G. Woolley, "Digital Literacies,” Dev. Lit. Second. Classr., pp. 170-186, 2018, doi: 10.4135/9781526415417.n11.

[5] A. Walqui and G. C. Bunch, "Reenvisioning literacy development for English learners: Amplifying the curriculum, amplifying leadership,” J. Adolesc. Adult Lit., vol. 63, no. 5, pp. 577-582, 2020, doi: https://doi.org/10.1002/jaal.1041.

[6] X. Li and Q. Liu, "Social Media Use, eHealth Literacy, Disease Knowledge, and Preventive Behaviors in the COVID-19 Pandemic: Cross-Sectional Study on Chinese Netizens," J Med Internet Res, vol. 22, no. 10, p. e19684, Oct. 2020, doi: 10.2196/19684.

[7] J. Bröder et al., "Health literacy in childhood and youth: a systematic review of definitions and models," BMC Public Health, vol. 17, no. 1, p. 361, 2017, doi: 10.1186/s12889-017-4267-y.

[8] Afrianto, "Being a professional teacher in the era of industrial revolution 4.0: opportunities, challenges and strategies for innovative classroom practices," English Lang. Teach. Res., vol. 2, no. 1, p. 3, 2018, [Online]. Available: http://ejournal.unp.ac.id/index.php/eltar/article/view/102675.

[9] V. Pavlou, "Art Technology Integration: Digital Storytellying as a Transformative Pedagogy in Primary Education,” Int. J. Art Des. Educ., vol. 39, no. 1, pp. 195-210, Feb. 2020, doi: https://doi.org/10.1111/jade.12254.

[10] F. Huettig and M. J. Pickering, "Literacy Advantages Beyond Reading: Prediction of Spoken Language," Trends Cogn. Sci., vol. 23, no. 6, pp. 464-475, 2019, doi: https://doi.org/10.1016/j.tics.2019.03.008.

[11] A. Al-Fadley, A. Al-Holy, and A. Al-Adwani, "Teacher perception of parents' involvement in their children's literacy and their reading instructions in Kuwait EFL primary school classrooms," Int. J. Educ. Pract., vol. 6, no. 3, pp. 120-133, 2018, doi: 10.18488/journal.61.2018.63.120.133.

[12] A. Matsuda, Preparing teachers to teach English as an international language. Multilingual Matters, 2017.

[13] G. A. P. D. P. Sari AR, "Storybook Reading Technique to Support Toddler Literacy Development in The New Normal Era," in New Normal: Idealism and Implementation in Indonesia and the Philippines, 1st ed., Denpasar: Jayapangus Press, 2020, pp. 67-79.

[14] M. de Bondt, I. A. Willenberg, and A. G. Bus, "Do Book Giveaway Programs Promote the Home Literacy Environment and Children's Literacy-Related Behavior and Skills?,” Rev. Educ. Res., vol. 90, no. 3, pp. 349-375, May 2020, doi: 10.3102/0034654320922140.

[15] R. Ewing, "Embedding arts-rich English and literacy pedagogies in the classroom," Lit. Learn. Middle Years, vol. 27, no. 1, pp. 7-17, 2019, [Online]. Available: https://search.informit.org/doi/10.3316/aeipt.222610.

[16] R. Syamsidar, "PACKAGING PRODUCT MODEL BASED ON INFORMATION," Turkish J. Physiother. Rehabil., vol. 32, no. 3, pp. 2681-2691, 2019.

[17] M.-B. Alexandrescu and M. Milandru, "PROMOTION AS A FORM OF COMMUNICATION OF THE MARKETING STRATEGY,” Rev. Acad. FORŢELOR Terest., vol. 12, no. 20, pp. 271-280, 2019, doi: 10.34079/2226-3055-2019-12-20-271-280.

[18] D. Chinn, "Learning how to be (a) patient: visual analysis of accessible health information leaflets for people with intellectual disabilities," Disabil. Soc., vol. 32, no. 10, pp. 1485-1509, Nov. 2017, doi: 10.1080/09687599.2017.1372271.

[19] D. Castillo-Zúñiga, "Design, Elaboration and Implementation of a Vocabulary Booklet to improve B2+ level students' speaking performance at a language school.," Univ. Piura, 2018, [Online]. Available: https://pirhua.udep.edu.pe/handle/11042/3437. 
[20] R. Amorati, "Making languages marketable: An analysis of a promotional brochure for prospective students in an Australian tertiary institution," Lang. Learn. High. Educ., vol. 8, no. 2, pp. 313-331, 2018, doi: doi:10.1515/cercles-2018-0018.

[21] S.-Y. Lee, Y.-H. G. Lo, and T.-C. Chin, "Practicing multiliteracies to enhance EFL learners' meaning making process and language development: a multimodal Problem-based approach," Comput. Assist. Lang. Learn., vol. 34, no. 1-2, pp. 66-91, Jan. 2021, doi: 10.1080/09588221.2019.1614959.

[22] V. Erdoğan, "Integrating 4C Skills of 21st Century into 4 Language Skills in EFL Classes," Int. J. Educ. Res., vol. 7, no. 11, pp. 113-124, 2019.

[23] P. R. Srinivas, "The Importance of Speaking Skills in English Classrooms," Alford Counc. Int. English Lit. Journal(ACIELJ), vol. Vol 2, no. Issue 2, p. 18, 2019, [Online]. Available: www.acielj.com.

[24] I. P. Y. Purandina and K. A. Wedananta, "Spirit of Balinese Local Heroes Transformed into Puppets Show on YouTube as ELT Media for Building Students' Character," J. Pendidik. dan Pengajaran, vol. 54, no. 1, p. 80, 2021, doi: 10.23887/jpp.v54i1.33001.

[25] A. R. Syuri and S. Widodo, "Development of Comic Learning Media for Fifth Grade Thematic Learning in Elementary School," vol. 6, no. 6, 2021.

[26] N. Sari and A. F. R. Sy., "Using Tourism Brochures in Teaching English," J. English Lang. Teach., vol. 1, no. March, pp. 97-105, 2013.

[27] R. N. R. Candra Kurniawan, "Using Tourism Brochure Pictures to Generate Ideas in Improving Junior High School Student's Speaking Ability,” J. English Lang. Teach., vol. 1, no. 2, pp. 292-300, 2013.

[28] B. B. ogli Joraboyev, "USING AUTHENTIC MATERIALS ON ENGLISH LESSONS Bahromjon Bakhtiyor ogli Joraboyev The 2 year student of Foreign Languages and Literature Chirchik State Pedagogical Institute of Tashkent region,” Acad. Reserach Educ. Sci., vol. 2, no. 2, pp. 1018-1025, 2021.

[29] M. Y. Damanhouri, "The Effectiveness of Scaffolding as a Teaching Strategy in Enhancing English Language Learners' Motivation in Writing: ACase Study," vol. 10, no. 03, pp. 49-58, 2021.

[30] F. Almeida, I. Superior, P. Gaya, A. Queirós, and D. Faria, "Strengths and Limitations of Qualitative and Quantitative Research Methods Innovation and Entrepreneurship View project Observatory of Portuguese Academic Spin-offs View project European Journal of Education Studies STRENGTHS AND LIMITATIONS OF QUALITATIVE AND QUANTITATIVE RESEARCH METHODS,” pp. 369-387, 2017, doi: 10.5281/zenodo.887089.

[31] H. Zaini et al., "Covid-19 and Islamic Education in School: Searching for Alternative Learning Media," Webology, vol. 18, no. 1, pp. 154-165, 2021, doi: 10.14704/WEB/V18I1/WEB18080.

[32] U. Flick, "Triangulation in Data Collection," SAGE Res. Methods, 2018, doi: https://dx.doi.org/10.4135/9781526416070.n34.

[33] K. Roulston, "Triangulation in qualitative research," QualPage, 2018. https://qualpage.com/2018/01/18/triangulation-in-qualitative-research/.

[34] I. P. A. Suhardiana and N. L. G. W. Lestari, "Enhancing Students' Literacy Skills through the use of English Storybooks," Yavana Bhasha J. English Lang. Educ., vol. 1, no. 1, p. 80, 2020, doi: 10.25078/yb.v1i1.1380.

[35] M. Myllymaa, “THE PROCESS OF DEVELOPING A BROCHURE FOR STUDENTS ABOUT LONELINESS," Diaconia University of Applied Sciences, 2021.

[36] A. Masrai, "Can L2 Phonological Vocabulary Knowledge and Listening Comprehension be Developed Through Extensive Movie Viewing? the Case of Arab EFL Learners," Int. J. List., vol. 34, no. 1, pp. 54-69, Jan. 2020, doi: 10.1080/10904018.2019.1582346.

[37] M. K. Yadav, "Role of Mother Tongue in Second Language Learning," Int. J. Res., vol. 1, no. 11, pp. 572-582, 2014, [Online]. Available: http://citeseerx.ist.psu.edu/viewdoc/download?doi=10.1.1.892.7707\&rep=rep1\&type=pdf.

[38] M. Yusitaria, "Using Tourism Brochures in Teaching Descriptive Writing to the Tenth Grade Hotel Accommodation Students of SMK Negeri 6 Palembang," UIN RADEN FATAH PALEMBANG, 2017. 
[39] F. T. Marsita, H. H. Hasan, and B. Kadaryanto, "THE USE OF BROCHURE IN INCREASING STUDENTS SPEAKING ABILITY,” U-JET Unila J. English Teach., vol. 3, no. 4, 2014.

[40] E. Namaziandost, "The Assessment of Oral Proficiency through Holistic and Analytic Techniques of Scoring: A Comparative Study," Appl. Linguist. Res. J., no. May, 2019, doi: 10.14744/alrj.2019.83792.

[41] S. Kothuri and R. Nageswari, "CLIL to develop hotel management (HTM) learners' vocabulary; Ongoing research,” Man India, vol. 97, no. 2, pp. 745-751, 2017. 